\title{
Freeze-drying microscopy in mathematical modeling of a biomaterial freeze-drying
}

\author{
Camila Figueiredo Borgognoni ${ }^{1, *}$, Joyce da Silva Bevilacqua ${ }^{2}$, \\ Ronaldo Nogueira de Moraes Pitombo ${ }^{1}$
}

\author{
${ }^{I}$ Department of Biochemical and Pharmaceutical Technology, Faculty of Pharmaceutical Sciences, \\ University of Sao Paulo, Sao Paulo, '2Department of Applied Mathematics, \\ Institute of Mathematics and Statistics, University of Sao Paulo, Sao Paulo
}

\begin{abstract}
Transplantation brings hope for many patients. A multidisciplinary approach on this field aims at creating biologically functional tissues to be used as implants and prostheses. The freeze-drying process allows the fundamental properties of these materials to be preserved, making future manipulation and storage easier. Optimizing a freeze-drying cycle is of great importance since it aims at reducing process costs while increasing product quality of this time-and-energy-consuming process. Mathematical modeling comes as a tool to help a better understanding of the process variables behavior and consequently it helps optimization studies. Freeze-drying microscopy is a technique usually applied to determine critical temperatures of liquid formulations. It has been used in this work to determine the sublimation rates of a biological tissue freeze-drying. The sublimation rates were measured from the speed of the moving interface between the dried and the frozen layer under 21.33, 42.66 and 63.99 Pa. The studied variables were used in a theoretical model to simulate various temperature profiles of the freeze-drying process. Good agreement between the experimental and the simulated results was found.
\end{abstract}

Uniterms: Freeze-drying microscopy. Bovine pericardium. Mathematical modeling.

A prática da transplantação traz esperança para muitos pacientes. Uma visão multidisciplinar nessa área visa à produção de tecidos biológicos para serem utilizados como implantes e próteses. A liofilização é um processo de secagem que preserva características essenciais desses materiais, facilitando sua manipulação e armazenamento. A liofilização é um processo que requer muito tempo e energia e sua otimização é muito importante, pois permite reduzir custos de processo melhorando a qualidade do produto. A modelagem matemática é uma ferramenta que permite descrever o comportamento do produto durante o processo e, consequentemente, auxilia os estudos de otimização. Microscopia óptica acoplada à liofilização, uma técnica usualmente aplicada na determinação de temperaturas críticas de formulações líquidas, foi utilizada neste trabalho na determinação de taxas de sublimação da liofilização de um tecido biológico. As taxas de sublimação foram calculadas a partir da velocidade da interface entre a camada seca e congelada, sob pressões de 21,33, 42,66 e 63,99 Pa. As variáveis estudadas foram usadas em um modelo matemático teórico, que simula os perfis de temperatura do produto durante o ciclo de liofilização. Os resultados apresentados demonstraram boa relação entre os dados experimentais e simulados.

Unitermos: Microscopia óptica acoplada à liofilização. Pericárdio bovino. Modelagem matemática.

\section{INTRODUCTION}

Freeze-drying is a gentle drying method widely used for sensitive products such as biopharmaceuticals

\footnotetext{
*Correspondence: C.F. Borgognoni. Departmento de Tecnologia BioquímicoFarmacêutica, Faculdade de Ciências Farmacêuticas, Universidade de São Paulo. Av. Prof. Lineu Prestes, 580, BL16, CP 66083 - 05508-900 - São Paulo - SP, Brasil. Email: caborg@usp.br
}

and foodstuffs (Tang, Pikal, 2004; Papavasiliou et al., 2008). When applied to biological human or animal tissues for regenerative medicine or tissue engineering purposes, the freeze-drying process allows fundamental properties of these materials to be preserved, making future manipulation and storage much easier (Aimoli et al., 2007; Borgognoni et al., 2010; Leirner, Tattini Jr, Pitombo, 2009). Freeze-drying is a very lengthy process 
when compared to other methods of drying because of the low drying rate and operation under reduced pressure. Thus, a non-optimized freeze-drying process could take excessive time and energy consumption becoming it into an expensive process. Therefore, optimization studies of the freeze-drying process have been performed by some researchers (Chakraborty et al., 2011; Chouvenc et al., 2004; Grant, Matehtschuk, Dalby, 2009). Mathematical modeling enhances the understanding of the freeze-drying process and becomes an effective manner of studying its optimization. A computer simulation run on these models is used to analyze drying rates and to predict the surface temperature profile (Liapis, Litchfield, 1979; Millman, Liapis, Marchello, 1985; Pisano, Fissore, Barresi, 2011). Heat and mass transfer models for the freeze-drying process have been developed by a number of researchers and these are presented in scientific literature (Sadikoglu, Liapis, 1997; Sheehan, Liapis, 1998; George, Datta, 2002).

Freeze-drying process consists basically of three steps: freezing, primary drying and secondary drying. In the primary drying step, the freezable water is removed from the frozen material by sublimation. As the sublimation starts at the surface of the material, the sublimation interface recedes leaving a porous zone of a dried material through which the water vapor moves towards the surface of the product directly to the condenser serpentines of the freeze-dryer. Secondary drying begins locally when all ice has been removed from that region. Thus some secondary drying proceeds simultaneously with primary drying in different regions of the same sample. At this point both unfrozen water and bound water is removed.

Many laboratory techniques have been used to determine a sublimation rate in the primary drying stage. Some authors have determined the primary drying rate by stopping the freeze-drying process at a fixed point and measuring the weight lost during this partial drying phase (Searles, Carpenter, Randolph, 2011; Chakraborry, Saha, Bhattacharya, 2006). Pikal et al. (1983) described a microbalance technique to determine sublimation rates by evaluating the dried layer resistance of different materials. Zhai et al. (2003) determined the values of the effective diffusion coefficients using freeze-drying microscopy.

Freeze-drying microscopy has been a technique usually used in the determination of critical temperatures of liquid formulations (Tattini Jr et al., 2007; Tattini Jr, Parra, Pitombo, 2009). It consists of a microscope coupled to a freeze-drying chamber that permits visual observations of the product during the freeze-drying process.

The aim of this work was to determine the sublimation rates during the primary drying of a biological tissue freeze-drying from the speed of the moving inter- face between the dried and the frozen layer visualized by freeze-drying microscopy. In addition, the effects of chamber pressure on the sublimation rate were quantified and, finally, the data predicted by the mathematical model were compared with the experimental results.

\section{MATERIAL AND METHODS}

Bovine pericardium was obtained from a local slaughterhouse, where it was cleaned to remove fat, and transported to the laboratory in a saline solution $(0.9 \%$ $(\mathrm{w} / \mathrm{v}) \mathrm{NaCl})$. Afterwards, the tissue was immersed into glycerin until the analyses were performed. Prior to the analyses, the samples were washed in a saline solution $(0.9$ $\%(\mathrm{w} / \mathrm{v}) \mathrm{NaCl}$ ) with continuous stirring for 15 minutes. The process was repeated 3 times to remove the excessive amount of glycerin.

\section{Freeze-drying}

Freeze-drying runs were performed in an FTS Systems freeze-dryer (model TDS-00209-A, New York, USA) that is a microprocessor-controlled tray dryer. Samples of $3 \mathrm{~cm}$ in diameter were placed on Petri dishes and frozen at $223 \mathrm{~K}$ (a thermocouple was inserted into a sample to determine the final temperature). A thermal treatment by annealing was applied by heating the frozen samples to $253 \mathrm{~K}$ and this temperature was held for 1 hour. Finally, the samples were cooled to $223 \mathrm{~K}$ and then freeze-dried. Primary drying was conducted at a shelf temperature of $268 \mathrm{~K}$ (heating rate of $0.025 \mathrm{~K} / \mathrm{s}$ ) and a pressure of 21.33 , 42.33 and $63.99 \mathrm{~Pa}$. The end of the primary drying phase was determined by a Hygrometer (Endress - Hauser). Thermocouples were placed in the center of the samples to measure their temperature. The temperature was measured every minute.

\section{Freeze-drying microscopy}

The freeze-drying microscope (Biopharma Technology Ltda, Surrey, UK) consisted of a small freeze-drying chamber containing a temperature-controlled stage, a vacuum pump, and a microscope (Olympus BX-51, Hertfordshire, UK) equipped with a condenser extension lens (Linkam, Surrey, UK) and a monochrome video camera (Imasys, Suresnes, France). A heating rate of $0.025 \mathrm{~K} / \mathrm{s}$ was used. Pressures of 21.33, 42.66 and $63.99 \mathrm{~Pa}$ were used to evaluate the effect of this parameter on the sublimation rates. A $3 \mathrm{~mm}$ in diameter sample of bovine pericardium was placed on the temperature-controlled stage between two cover glasses. Thermal treatment by 
annealing was applied by heating the frozen samples to $253 \mathrm{~K}$ and the temperature was held for 1 hour at this fixed temperature. Finally, the samples were cooled to $223 \mathrm{~K}$ and the samples were freeze-dried. Sublimation occurred from the outer borders toward the center of samples. The sublimation rate $\left(\mathrm{N}_{\mathrm{f}}\right)$ was determined by measuring the depth (thickness) of the dried layer every minute.

\section{Mathematical model}

The model, based on the work of Liapis and Litchfield (1979), consists of an unsteady state energy balance in the dried and frozen regions.

$$
\begin{aligned}
\frac{\partial T_{I}}{\partial t} & =-\frac{N_{t} c_{p v}}{\rho_{I} c_{p I}} \frac{\partial\left(T_{I}\right)}{\partial x}+\alpha_{I} \frac{\partial^{2} T_{I}}{\partial x^{2}}, 0 \leq \mathrm{x} \leq \mathrm{X} \\
\frac{\partial T_{I I}}{\partial x} & =\alpha I\left(\frac{\partial^{2} T_{I I}}{\partial x^{2}}\right), \mathrm{X} \leq \mathrm{x} \leq \mathrm{L}
\end{aligned}
$$

The one-dimensional system is shown in Figure 1. Liapis and Litchfield (1979) presented a model of the freeze-drying of a product in trays where only one surface was exposed to ambient. In this work, two glass covers were placed under and above the sample exposing only the sides of a sample. This situation creates the same conditions used in the work of Liapis and Litchfield (1979) with heat and mass flowing in one direction only. In the freezedrying process, a drying layer builds up continuously creating an interface of sublimation - the sublimation front. This front which separates the dried and frozen layers of the material, moves toward the center of the sample $(\mathrm{x}=\mathrm{L})$ when drying progresses. The heating shelf provides energy for sublimation and controls the rate of heat transmission (q) to the product. The heat flux goes towards the frozen layer in the radial direction. The pressure is kept constant during drying. The water vapor diffuses through the porous dried layer and leaves the material to be collected in the

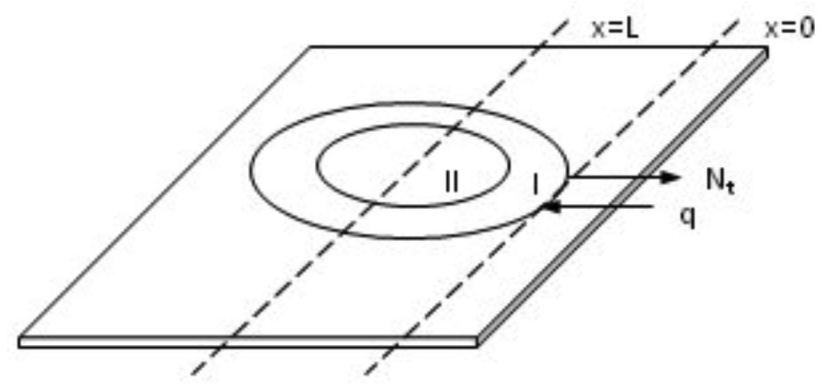

FIGURE 1 - Schematic of the system considered. condenser. The primary drying ends when there is no more drying layer present in the matrix.

The following assumptions were used when developing a mathematical model for freeze drying of a biological tissue:

1) One-dimensional heat and mass flows, normal to the interface and the surface, are considered.

2) Sublimation occurs at an interface parallel to, and at a distance $X$ from the surface of the sample.

3) The thickness of the interface is considered to be infinitesimal.

4) The frozen region is considered to remain at a temperature equal to the interface temperature, of uniform thermal conductivity, density, and specific heat.

5) In the porous region, the solid matrix and the enclosed water vapor are in thermal equilibrium.

All sides of the sample are insulated except for circumference (side area) of the sample. In the dried layer effective parameters have been considered to be independent of space.

The initial and boundary conditions are:

$$
\begin{array}{ll}
T_{I}=T_{I I}=T_{0} & \text { at } \mathrm{t}=0,0=\mathrm{x}=\mathrm{L} \\
q=-k_{I} \frac{\partial T_{I}}{\partial x} & \text { at } \mathrm{x}=0, \mathrm{t}>0 \\
T_{I}=T_{I I}=T_{x} & \text { at } \mathrm{x}=\mathrm{X}, \mathrm{t}>0
\end{array}
$$

The heat transfer mechanism considered in the system is only through radiation since the pressure applied is very low.

For radiation only,

$$
q=\sigma F\left(T_{S}^{4}-T_{I}^{4}\right) \text { at } \mathrm{x}=0, \mathrm{t}>0
$$

The sublimation rate is modeled by the expression, given by a material balance at the interface:

$$
N_{t}=-n \rho_{I I} \frac{\partial X}{\partial t}
$$

The sublimation rate $\left(\mathrm{N}_{\mathrm{t}}\right)$ was calculated from the thickness of the dried layer by photographs obtained from freeze-drying microscopy. The densities $(\rho)$ were measured using a pycnometer and a digital balance. The porosity (n) was determined by a Hidrosorb 1000 (Quantachrome Instruments). The bovine pericardium thermal properties were measured using a DSC-50 cell (Shimadzu). These data were incorporated into equation 1, and the model was solved using MATHCAD 13.0 software in which partial differential equations were solved by the method of lines (Schiesser, 1991). 


\section{RESULTS AND DISCUSSION}

Based on images of the freeze-drying progress obtained from freeze-drying microscopy observation, as shown in Figure 2, the thickness of the dried layer of the tissue was determined. It was observed that the thickness of the dried layer under different pressures was a function of time (Figure 3A). The data were well fitted with cubic splines. The interface velocity could be calculated from derivation of thickness data. Figure 3B shows the interface velocities as a function of time for different chamber pressures. Interface velocity decreased as pressure was raised.

The sublimation rates were calculated based on equation 7 for different chamber pressures (Figure 4).

Bovine pericardium temperatures during freezedrying at studied pressures were simulated using equation (1) with the sublimation rate data gathered at the corresponding pressure. Table I gives the parameters and values used in this simulation.

The mathematical model allowed the determination of temperature profiles of the product during freezedrying time in various interface positions (Figure 5). This measurement would be impossible to be determined experimentally by a thermocouple because the position of sublimation interface is dynamic toward the center of the sample.

The measurement of the product temperature during freeze-drying was done by thermocouples inserted in the material. In freeze-drying of products in vials and shelves the thermocouples were placed in the bottom of the sample to determine the product temperature in the primary drying when all ice crystals were sublimated.

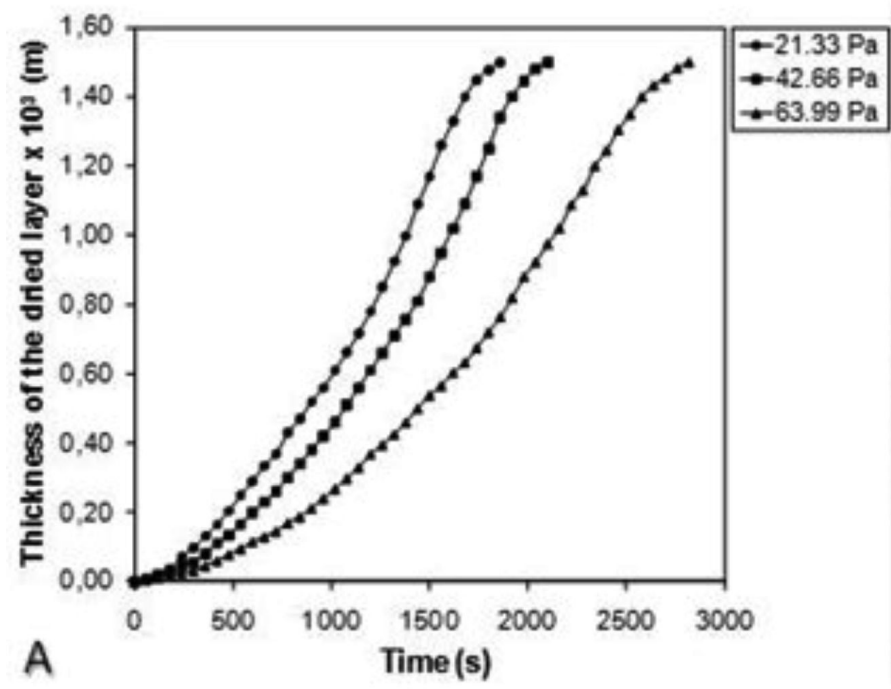

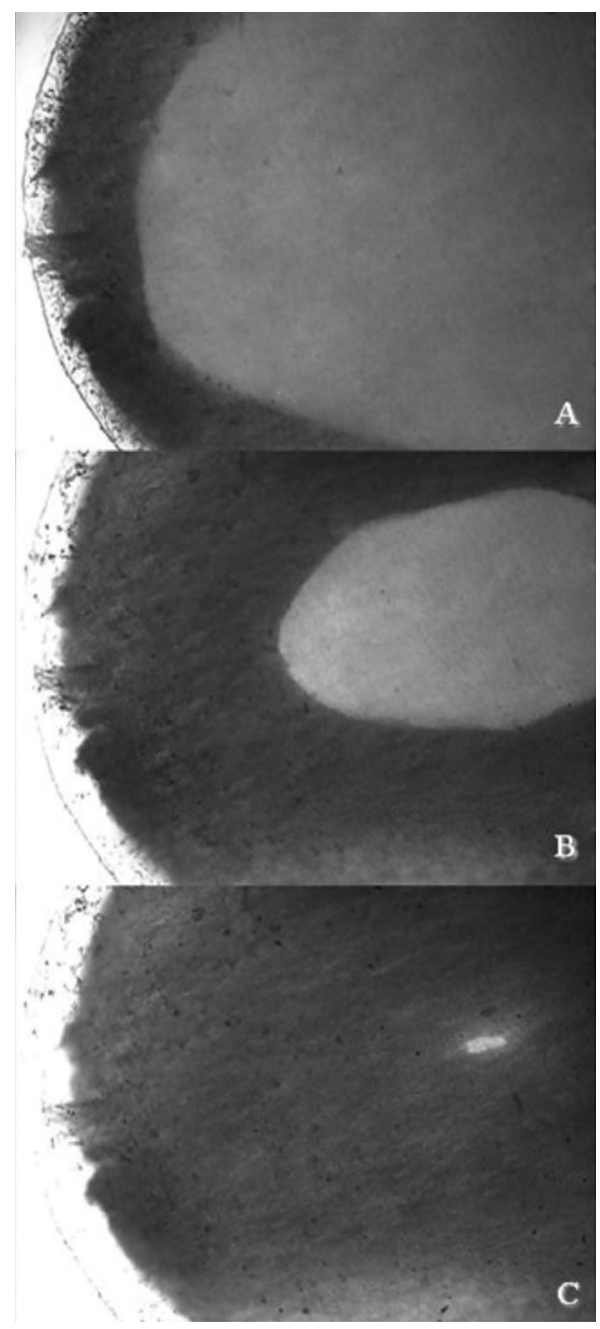

FIGURE 2 - Microscopic observation of the bovine pericardium freeze-drying at $21.33 \mathrm{~Pa}$ and $1.5^{\circ} \mathrm{C} / \mathrm{min}$, after (A) $8 \mathrm{~min}$, (B) $16 \mathrm{~min}$ and (C) $24 \mathrm{~min} .100 \mathrm{x}$ magnification.

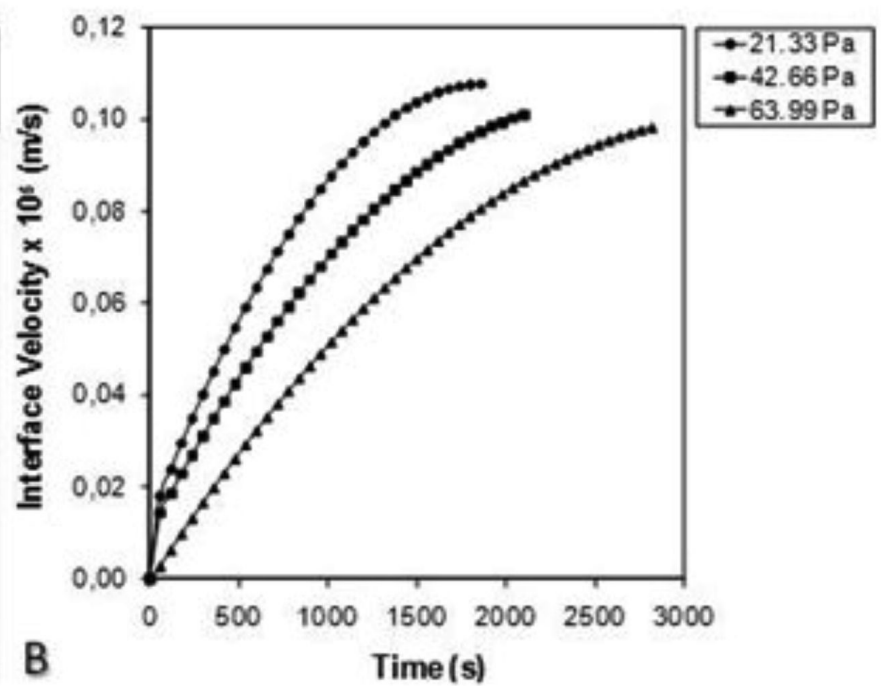

FIGURE 3 - (A) Thickness of the dried layer as a function of time during freeze-drying of bovine pericardium at different pressures. (B) Interface velocity as a function of time during freeze-drying of bovine pericardium at different pressures. 


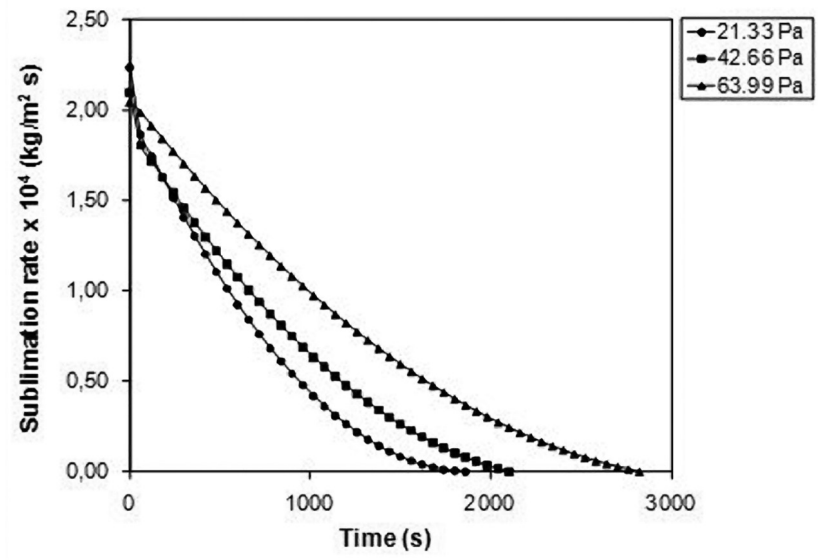

FIGURE 4 - Sublimation rate as a function of time during freezedrying of bovine pericardium at different pressures.

TABLE I - Parameters required in freeze-drying mathematical modeling

\begin{tabular}{cc}
\hline Parameters & Values \\
\hline $\mathrm{c}_{\mathrm{pv}}$ & $1.883 \mathrm{~kJ} /(\mathrm{kg} \mathrm{K})^{*}$ \\
$\mathrm{c}_{\mathrm{pI}}$ & $0.02186 \mathrm{~kJ} /(\mathrm{kg} \mathrm{K})$ \\
$\mathrm{c}_{\mathrm{pII}}$ & $0.01025 \mathrm{~kJ} /(\mathrm{kg} \mathrm{K})$ \\
$\rho_{\mathrm{I}}$ & $0.3810^{3} \mathrm{~kg} / \mathrm{m}^{3}$ \\
$\rho_{\mathrm{II}}$ & $1.3010^{3} \mathrm{~kg} / \mathrm{m}^{3}$ \\
$\alpha_{\mathrm{I}}\left(=\mathrm{k}_{\mathrm{I}} /\left(\rho_{\mathrm{I}} \mathrm{c}_{\mathrm{pI}}\right)\right)$ & $0.000065 \mathrm{~m}^{2} / \mathrm{s}$ \\
$\mathrm{n}$ & 0.16 \\
$\mathrm{k}_{\mathrm{I}}$ & $0.00054 \mathrm{~kW} /(\mathrm{m} \mathrm{K})$ \\
$\mathrm{k}_{\mathrm{II}}$ & $0.00131 \mathrm{~kW} /(\mathrm{m} \mathrm{K})$ \\
\hline
\end{tabular}

${ }^{*}$ Results published by Bhattacharya and Mahajan (2003) and Chakraborry and Bhattacharya (2006).

In case of bovine pericardium the thermocouples should be positioned at the geometric center of the sample since the freeze-drying occurs from the edges toward the center of the sample. The bovine pericardium is a solid product with a very thin thickness and then the insertion of thermocouples at the geometric center of the sample is inaccurate.

The temperature profiles of the product that best correlated the experimental data obtained at pressures of $21.33,42.33$ and $63.99 \mathrm{~Pa}$ were respectively obtained in the interface positions of $0.4 \mathrm{~L}, 0.4 \mathrm{~L}$ and $0.6 \mathrm{~L}$ (correlation coefficients around $0.97,0.96$ and 0.96 ) considering that freeze-drying is a complex process (Bhattacharya, Mahajan, 2003) and inherent experimental errors in measuring accurately the thickness of the dried layer at a given time. Thus, the model allowed the positioning of the thermocouple in the sample during the freeze-drying process.

The comparison between the temperature profiles predicted by the model and those obtained experimentally is shown in Figure 6.
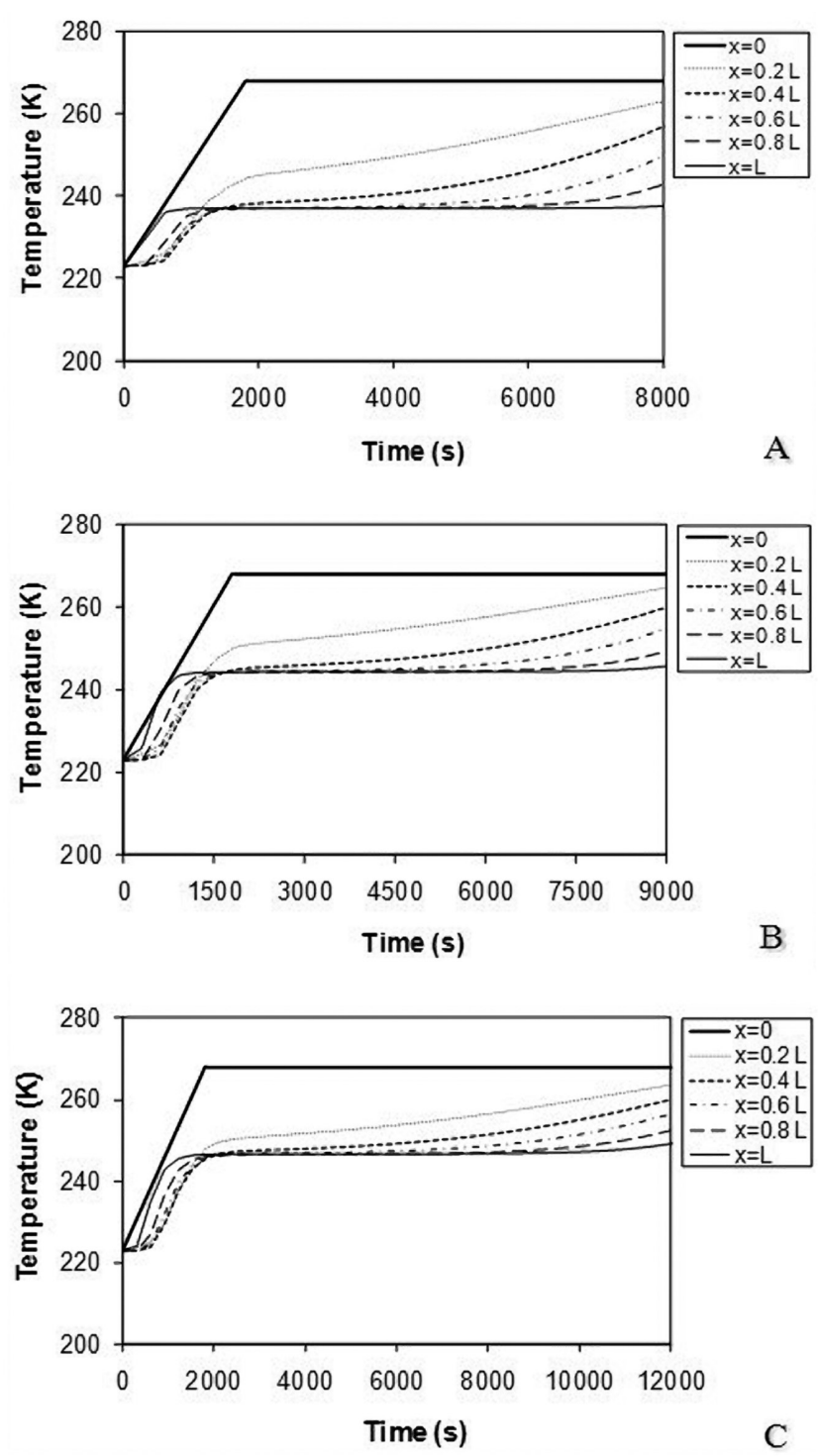

FIGURE 5 - Bovine pericardium temperature versus time during freeze-drying by mathematical modeling at (A) $21.33 \mathrm{~Pa}$, (B) 42.33 $\mathrm{Pa}$ and (C) 63.99 Pa.

The primary drying time was obtained experimentally by dew points data provided by the hygrometer coupled to the freeze-drier. The simulated data were obtained with the disappearance of the interface of sublimation.

Table II shows the simulated and experimental freeze-drying time at 21.33, 42.33 and $63.99 \mathrm{~Pa}$.

The data give evidence that the model used in this study was applicable to biomaterials. Furthermore, it was verified that freeze-drying microscopy could be used for determination of the sublimation rate of a biomaterial at different conditions through measurement of the thickness of the dried layer formed during the freeze-drying process. The method allows monitoring the sample behavior during the freeze-drying process that is of great importance to process modeling. 
TABLE II - Experimental and simulated freeze-drying time at different chamber pressures

\begin{tabular}{ccc}
\hline Pressure & \multicolumn{2}{c}{ Freeze-drying time $(\mathrm{s})$} \\
\cline { 2 - 3 }$(\mathrm{Pa})$ & Experimental & Simulated \\
\hline 21.33 & $7620 \pm 217$ & $7718 \pm 100$ \\
42.33 & $7980 \pm 922$ & $8669 \pm 669$ \\
63.99 & $11040 \pm 1029$ & $11806 \pm 948$ \\
\hline
\end{tabular}

$($ mean $\pm \mathrm{SD}), \mathrm{n}=3$.
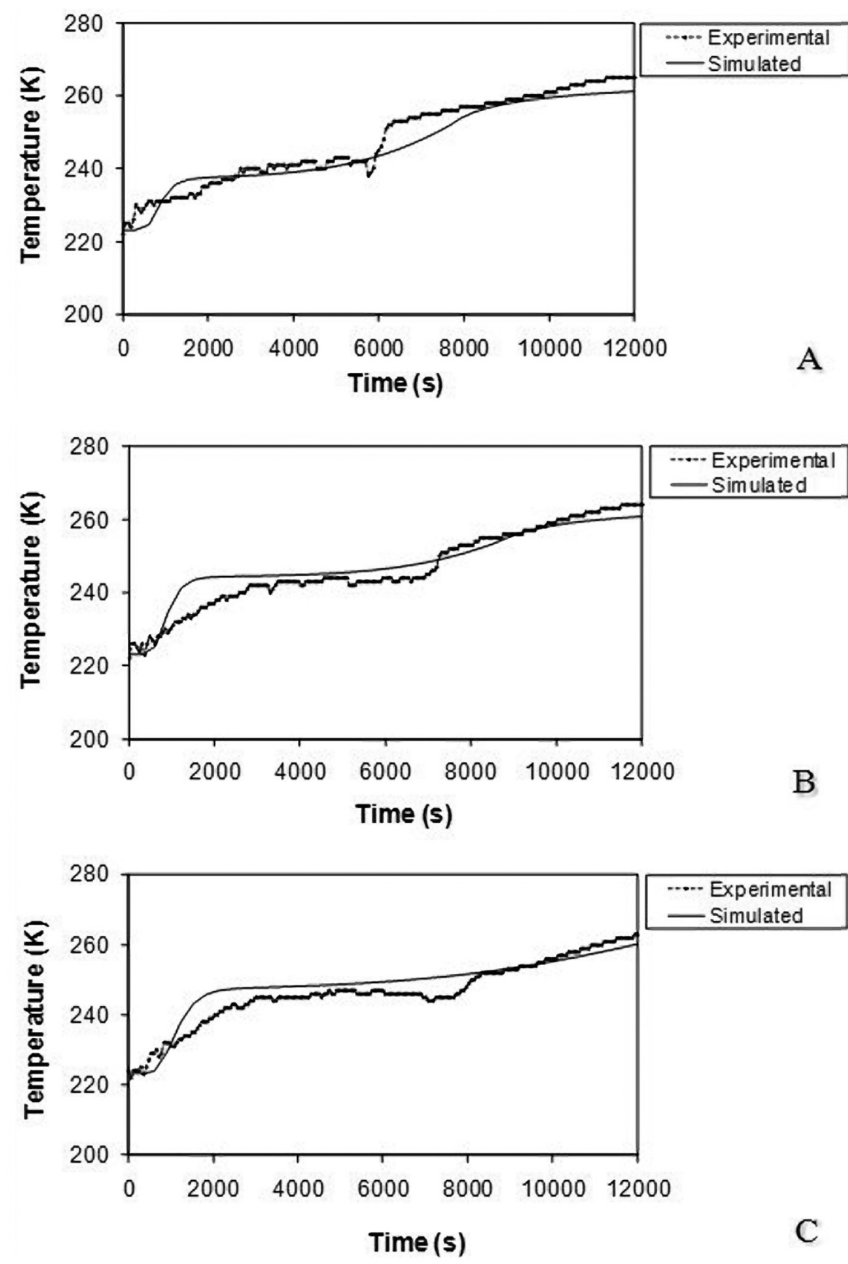

FIGURE 6 - Comparison between experimental and simulated temperature profiles of bovine pericardium freeze-drying at (A) 21.33 Pa ( $\mathrm{x}=0.4 \mathrm{~L}),(\mathrm{B}) 42.33 \mathrm{~Pa}(\mathrm{x}=0.4 \mathrm{~L})$ and (C) 63.99 $\mathrm{Pa}(\mathrm{x}=0.6 \mathrm{~L})$.

\section{CONCLUSIONS}

The mathematical model developed using freezedrying microscopy measurements fitted well to the experimental data. It has been observed that the sublimation rate was influenced by the chamber pressure of bovine pericardium freeze-drying. The model allowed predicting the temperature profile during the primary drying stage and the positioning of the thermocouple in the sample during the freeze-drying process. The monitoring of sample behavior and prediction of freeze-drying time could also be possible.

\section{ACKNOWLEGMENTS}

The financial support of the Foundation for Research Support of the State of Sao Paulo (FAPESP) is gratefully acknowledged.

\section{NOMENCLATURE}

$\mathrm{N}_{\mathrm{t}}$ sublimation rate, $\mathrm{kg} /\left(\mathrm{m}^{2} \mathrm{~s}\right)$

$\mathrm{T}$ temperature, $\mathrm{K}$

$\mathrm{t}$ time, $\mathrm{s}$

$\mathrm{x}$ space coordinate

$\mathrm{X}$ interface position, $\mathrm{m}$

$\mathrm{c}_{\mathrm{p}}$ specific heat, $\mathrm{kJ} /(\mathrm{kg} \mathrm{K})$

$\mathrm{L}$ sample radius, $\mathrm{m}$

$\mathrm{k}$ thermal conductivity, $\mathrm{kW} /(\mathrm{m} \mathrm{K})$

n porosity, -

$\mathrm{q}$ heat flux, $\mathrm{kW} / \mathrm{m}^{2}$

$\mathrm{F}$ emissivity factor

Subscripts

I dried region

II frozen region

$\mathrm{v}$ water vapor

o initial value

$s$ shelf

Greek Symbols

$\rho$ density, $\mathrm{kg} / \mathrm{m}^{3}$

$\alpha$ thermal diffusivity, $\mathrm{m}^{2} / \mathrm{s}$

$\sigma$ Stefan-Boltzman constant, $\mathrm{J} / \mathrm{K}$

\section{REFERENCES}

AIMOLI, C.G.; NOGUEIRA G.M.; NASCIMENTO L.S.; BACETI, A.; LEIRNER, A.A.; MAIZATO, M.J.S.; HIGA, O.Z.; POLAKIEWICZ, B.; PITOMBO, R.N.M.; BEPPU, M.M. Lyophilized bovine pericardium treated with a phenethylamine-diepoxide as an alternative to preventing calcification of cardiovascular bioprosthesis: preliminary calcification results. Artif. Organs, v.31, p.278-283, 2007.

BHATTACHARYA, A.; MAHAJAN, R.L. Temperature dependence of thermal conductivity of biological tissues. Physiol. Meas., v.24, p.769-783, 2003. 
BORGOGNONI, C.F.; MAIZATO, M.; LEIRNER, A.A.; POLAKIEWICZ, B.; BEPPU, M.; HIGA, O.Z.; PITOMBO, R.N.M. Effect of freeze-drying on the mechanical, physical and morphological properties of glutaraldehyde-treated bovine pericardium. J. Appl. Biomater. Biomech., v.8, p.186-190, 2010.

CHAKRABORTY, R.; BERA, M.; MUKHOPADHYAY, P.; BHATTACHARYA, P. Prediction of optimal conditions of infrared assisted freeze-drying of aloe vera (Aloe barbadensis) using response surface methodology. Sep. Purif. Technol., v.80, p.375-384, 2011.

CHAKRABORRY, R.; SAHA, A.K.; BHATTACHARYA, P. Modeling and simulation of parametric sensitivity in primary freeze-drying of foodstuffs. Sep. Purif. Technol., v.49, p.258-263, 2006.

CHOUVENC, P.; VESSOT, S.; ANDRIEU, J.; VACUS, P. Optimization of the freeze-drying cycle: A new model for pressure rise analysis. Drying Technol., v.22, p.1577-1601, 2004.

GEORGE, J.P.; DATTA, A.K. Development and validation of heat and mass transfer models for freeze-drying of vegetable slices. J. Food Eng., v.52, p.89-93, 2002.

GRANT, Y.; MATEJTSCHUK. P.; DALBY, P.A. Rapid optimization of protein freeze-drying formulations using ultra scale-down and factorial design of experiment in microplates. Biotechnol. Bioeng., v.104, p.957-964, 2009.

LEIRNER, A.A.; TATTINI JR, V.; PITOMBO, R.N.M. Prospects in Lyophilization of Bovine Pericardium. Artif. Organs, v.33, p.221-229, 2009.

LIAPIS, A.I.; LITCHFIELD, R.J. Optimal control of the freeze dryer. I: theoretical development and quasisteady-state analysis. Chem. Eng. Sci., v.34, p.975-981, 1979.

MILLMAN, M.J.; LIAPIS, A.I.; MARCHELLO, J.M. An analysis of the lyophilization process using a sorptionsublimation model and various operation policies. AlChE J., v.31, p.1594-1604, 1985.

PAPAVASILIOU, G.; KOURKOUTAS, Y.; RAPTI, A.; SIPSAS, V.; SOUPIONI, M.; KOUTINAS, A.A. Production of freeze dried kefir culture using whey. Int. Dairy J., v.18, p.247254, 2008.

PIKAL, M.J.; SHAH, S.; SENIOR, D.; LANG, J.E. Physical chemistry of freeze-drying: Measurement of sublimation rates for frozen aqueous solutions by a microbalance technique. J. Pharm. Sci., v.72, p.635-650, 1983.
PISANO, R.; FISSORE, D.; BARRESI, A.A. Freeze-drying cycle optimization using model predictive control techniques. Ind. Eng. Chem. Res., v.50, p.7363-7379, 2011.

SADIKOGLU, H.; LIAPIS, A.I. Mathematical modeling of the primary and secondary drying stages of bulk solution freeze drying in trays: parameter estimation and model discrimination by comparison of theorical results with experimental data. Drying Technol., v.15, p.791-810, 1997.

SEARLES, J.A.; CARPENTER, J.F.; RANDOLPH, T.W. Annealing to optimize the primary drying rate, reduce freezing-induced drying rate heterogeneity, and determine Tg in pharmaceutical lyophilization. J. Pharm. Sci., v.90, p.872-887, 2001.

SCHIESSER, W.E. The numerical method of lines: integration of partial differential equations. San Diego: Academic Press; 1991. 326 p.

SHEEHAN, P.; LIAPIS, A.I. Modeling of the primary and secondary drying stages of the freeze-drying of pharmaceutical products in vials: numerical results obtained from the solution of a dynamic and spatially multidimensional lyophilization model for different operational policies. Biotechnol. Bioeng., v.60, p.712-728, 1998.

TANG, X.; PIKAL, M.J. Design of freeze-drying processes for pharmaceuticals: practical advice. Pharm. Res., v.21, p.191-200, 2004.

TATTINI JR, V.; MATOS, J.R.; POLAKIEWICZ, B.; PITOMBO, R.N.M. Evaluation of shrinkage temperature of bovine pericardium tissue for bioprosthetic heart valve application by differential scanning calorimetry and freezedrying microscopy. Mater. Res., v.10, p.1-4, 2007.

TATTINI JR, V.; PARRA, D.; PITOMBO, R.N.M. The influence of crucible material on the DSC thermal analysis compared to freeze-drying microscopy results. J. Therm. Spray Technol., v.98, p.203-206, 2009.

ZHAI, S.; TAYLOR, R.; SANCHES, R.; SLATER, N.K.H. Measurement of lyophilization primary drying rates by freeze-drying microscopy. Chem. Eng. Sci., v.58, p.23132323, 2003.

Received for publication on $23^{\text {rd }}$ January 2012 Accepted for publication on $28^{\text {th }}$ March 2012 
